\title{
Rhyolite lava dome growth styles at Chaitén Volcano, Chile (2008-2009): Interpretation of thermal imagery
}

\author{
Marc Bernstein ${ }^{1}$, Andrés Pavez ${ }^{2}$, Nick Varley ${ }^{3}$, Patrick Whelley ${ }^{1,4}$, Eliza S. Calder ${ }^{1}$ \\ ${ }^{I}$ Department of Geology, University at Buffalo, 411 Cooke Hall, Buffalo NY 14260-1350 USA. \\ mlb33@buffalo.edu; ecalder@buffalo.edu \\ ${ }^{2}$ Departamento de Geofisica, Universidad de Chile, Avda. Blanco Encalada 2002, Santiago, Chile. \\ apavez@dgf.uchile.cl \\ ${ }^{3}$ Facultad de Ciencias, Universidad de Colima, Colima, Col., 28045, México. \\ nick@ucol.mx \\ ${ }^{4}$ Present address:The Earth Observatory of Singapore, Nanyang Technological University, 50 Nanyang Avenue, 639798, Singapore. \\ pwhelley@ntu.edu.sg
}

\begin{abstract}
Airborne thermal images of the Chaitén rhyolite lava dome were obtained on three occasions between January 2009 and January 2010. These images were useful for understanding the nature and pace of growth of the newly extruded lava, which formed a complex of lobes and a spine. The images also revealed contrasting growth styles affecting different parts of the lava dome complex. Observed synchronous endogenous and exogenous growth was likely the result of multiple flow paths within the lava dome. We suggest that contrasts in morphology and surface texture between various lava lobes are the result of different extrusion rates.
\end{abstract}

Keywords: Chaitén Volcano, Rhyolite, Lava dome, Thermal imaging.

RESUMEN. Estilos de crecimiento del domo de lava riolítico del Chaitén (2008-2009): Interpretación de imágenes térmicas. Se obtuvieron imágenes térmicas aéreas del domo de lava riolítico Chaitén en tres ocasiones entre enero de 2009 y enero de 2010. Las imágenes fueron útiles para comprender la naturaleza y la tasa de crecimiento de la lava recién extruida, cuyos productos forman un complejo de lóbulos y una espina. Las imágenes también revelaron contrastantes estilos de crecimiento que afectaron las distintas partes del complejo de domos de lava. El crecimiento sincrónico endógeno y exógeno observado es probablemente el resultado de múltiples trayectorias de flujo en el interior del domo de lava. En resumen, el análisis de las imágenes térmicas permitió inferir que los contrastes en la morfología y textura de la superficie de los lóbulos de lava fueron el resultado de las diferentes tasas de extrusión. 


\section{Introduction}

Chaitén Volcano comprises a 3-km-diameter caldera occupied by a rhyolitic dome located in the Southern Volcanic Zone of the Chilean Andes centered at $42^{\circ} 59^{\prime}$ south and $72^{\circ} 38^{\prime}$ 'west (Fig. 1). Chaitén's eruptive history prior to 2008 was not well known. There is evidence of post-glacial prehistoric activity dated at $9370{ }^{14} \mathrm{C}$ BP that might represent the age of the caldera (Naranjo and Stern, 2004). Aerial photographs of the Chaitén dome taken before the 2008 activity show that part of the lava dome was vegetation free. Considering the location of this volcano in a high-rainfall maritime climate where adjacent ranges are heavily forested, this lack of vegetation suggests that there has been more recent activity. Recent radiocarbon dating indicates multiple eruptions younger than 5000 years BP, with a possible historical eruption in the $17^{\text {th }}$ century (Lara et al., 2013, this volume; Watt et al., 2013, this volume).

The most recent eruption of Chaitén Volcano started in May 2008 (Carn et al., 2009; Lara, 2009; Major and Lara, 2013, this volume). The eruption started with an explosive phase that lasted about two weeks. This explosive phase was followed by a transitional explosive-extrusive phase, an exogenous growth phase, a spine growth phase and finally an endogenous growth phase (Pallister et al., 2013, this volume). Although degassing continued into 2013, dome growth appears to have ceased sometime in late 2009 or earliest 2010. The eruption is of considerable interest because it is the first caldera rhyolite eruption for which there exists some monitoring data. This contrasts with the well-known Katmai/Novarupta rhyolite eruption of 1912 in Alaska that was essentially unobserved at the time (Griggs, 1922; Hildreth and Fierstein, 2012). Also, the 2008-2009 eruption formed a large, fast-growing and complex lava dome that eventually covered most of the pre-historic lava dome (Pallister et al., 2013, this volume).

Tephra dispersion from the early explosive phase in May 2008 is discussed by Watt et al. (2009) and Alfano et al. (2011). Analysis of leachates from ash fallout is presented by Durant et al. (2012). Meltfracture degassing of $\mathrm{H}_{2} \mathrm{O}$ from rhyolite at Chaitén and degassing of $\mathrm{Cl}, \mathrm{F}, \mathrm{Li}$ and $\mathrm{Be}$ are explored by Castro et al. (2012) and Lowenstern et al. (2012) respectively. Vesiculation and fragmentation of the May 2008 explosive pumice is discussed in Alfano et al. (2012).
Petrological evidence suggests that the rise of the rhyolitic magma was particularly rapid, arriving at the surface from a depth of at least $5 \mathrm{~km}$ in just 4 hours (Castro and Dingwell, 2009). Modeling of surface deformation observed in InSAR imagery from the L-band PALSAR instrument on the ALOS satellite suggests that the magma feeding Chaitén rose through a dike from an inclined rhyolite magma reservoir at a depth of 8 to $12 \mathrm{~km}$ (Wicks et al., 2011).

In this paper we present our interpretations of lava dome growth processes and structures based on thermal images obtained on three separate overflights that took place on 21 January 2009, 25 February 2009, and 24 January 2010. We discuss morphological, textural and thermal features identified in our imagery in terms of their relevance to hazards monitoring. We identify changes in dome activity with time, and analyze observed features in the context of analog dome-growth models from the literature. We also consider the relationship between surface textures and extrusion rates. Finally, we integrate our observations into the spatial and temporal framework of the 20082009 Chaitén eruption presented by other authors in this volume.

\section{Previous Thermal Imaging Studies of Lava Domes}

Monitoring of volcanoes using thermal infrared (TIR) imagery began several decades ago; however, the growing availability of portable TIR imaging cameras has increased their use in monitoring volcanic activity. As the examples in this section show, TIR images have been especially useful for monitoring the exogenous and endogenous growth of lava domes. The advantages and utility of TIR cameras for monitoring lava domes include the capability to: 1. Monitor eruptive activity from a safe distance; 2 . Image eruptions through thin cloud cover and fumarole condensation plumes; 3. Locate the hottest and most active parts of a lava dome; 4. Interpret growth structures and their evolution with time; and 5. Identify the parts of the dome that present the greatest hazards.

Many thermal imaging studies have focused on lava flows, fire fountains, and lava lakes (a comprehensive listing of relevant papers can be found in Spampinato et al. (2011) and Ramsey and Harris (2013)). Relatively few thermal studies have been conducted at lava domes. One reason for this discrepancy is the time scale over which the eruptive phenomena occur. Whereas high intensity volcanic 


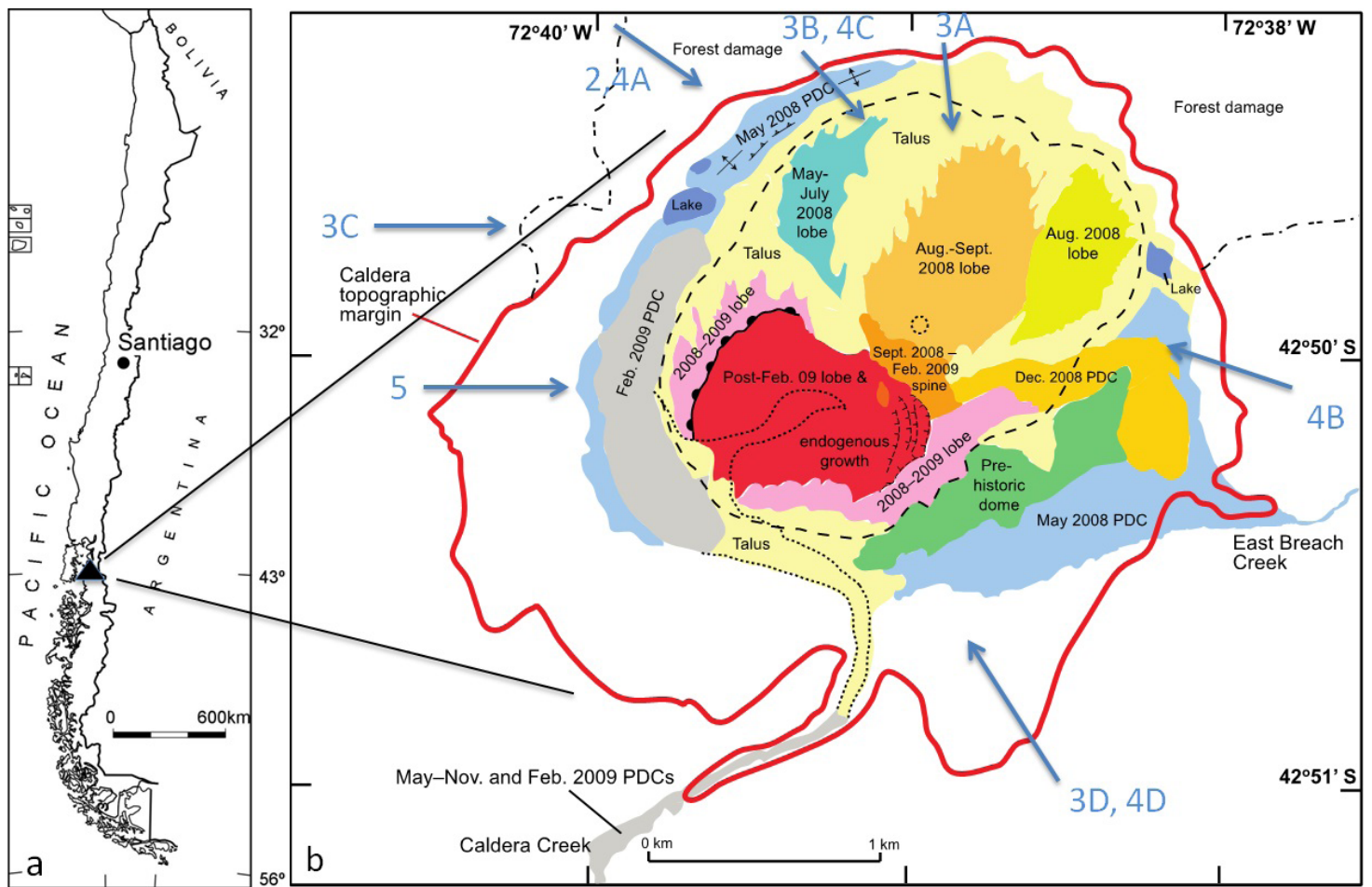

FIG. 1. a. Location map for Chaitén Volcano. b. Geologic map of the Chaitén Volcano as of January 2010 from Pallister et al. (2013, this volume). The feature names on the map differ from those used in reports by the Observatorio Volcanológico de los Andes del Sur and in this paper (see Table 1 for a correlation). All dated lobes are parts of Dome 1, except for the Aug.-Sept. 08 lobe, which is Dome 2, and the Post-Feb 09 lobe, which is Dome 3. The Spine is located between Domes 2 and 3. The blue numbered arrows indicate the approximate viewing direction of the thermal images.

processes, such as fire fountains or density currents, occur over seconds to hours, tracking the growth of a lava dome requires weeks to months and sometimes years of monitoring. Unfortunately, observing conditions and logistical issues often interfere with continuous monitoring at these time scales. This is particularly true at Chaitén Volcano, which is relatively remote and often shrouded in clouds. As a result, opportunities to acquire optical observations of a lava dome's activity are commonly limited.

The first lava dome eruption to be monitored using airborne thermal imaging was the extrusion of the post-climactic dacite lava dome at Mount St. Helens, USA, in 1980. Despite equipment limitations, Friedman et al. (1981) and Kieffer et al. (1981) were able to identify heating of the crater floor prior to dome extrusion, and to identify domegrowth-related fractures in the crater floor and the dome. These studies showed that thermal imaging had potential utility as a lava dome monitoring tool.
During the 1990-1992 eruption of Unzen Volcano, Japan, Umakoshi et al. (1992) used a TIR video camera to obtain spot temperatures of the andesitic to dacitic domes, flow lobes and associated blockand-ash-flow deposits. As a result, they were able to constrain the source regions of flows and lobes and areas of active dome growth. High temperatures were consistently found at the active faces of extruding shear lobes from which rockfalls and block-and-ash flows occurred. This work demonstrated the ability of thermal imaging to identify the actively hazardous parts of a lava dome.

Studies of Bezymianny and Sheveluch Volcanoes, Kamchatka, in 2005-2007 captured dome lobe and crater morphology with a 320x240 pixel TIR camera. (Carter et al., 2007; Carter et al., 2008; Carter and Ramsey, 2009; Ramsey et al., 2012). These studies showed that thermal imaging can identify structures and processes that may not otherwise be visible, and that airborne or ground-based thermal 
TABLE 1. CORRELATION AMONG CHAITÉN LAVA DOME LOBE TERMINOLOGIES.

\begin{tabular}{cll}
\hline OVDAS & This paper & Pallister et al. (2013, this volume) \\
\hline Domo 1 & Dome 1 & $\begin{array}{l}\text { May-July 08 lobe } \\
08-09 \text { lobe }\end{array}$ \\
Domo 2 & Dome 2 & $\begin{array}{l}\text { Aug. 08 lobe } \\
\text { Aug.-Sep. 08 lobe }\end{array}$ \\
Domo 3 & Dome 3 & $\begin{array}{l}\text { Post-Feb. 09 lobe and } \\
\text { endogenous growth }\end{array}$ \\
Pináculo & Spine & Sep. 08-Feb. 09 Spine \\
\hline
\end{tabular}

imaging has an important role in ground-truthing satellite thermal data.

The Caliente vent at Santiaguito, Guatemala, was imaged in 2005 with a $640 \times 480$ pixel thermal camera (Sahetapy-Engel and Harris, 2009). Caliente is often referred to as a lava dome. However, Sahetapy-Engel and Harris (2009) confirmed that rather than being occupied by a typical dome, the Caliente vent is occupied by a pancake-shaped blocky lava flow.

Thermal imaging was used extensively by the United States Geological Survey's Alaska and Cascades Volcano Observatories to monitor the nature and pace of lava dome growth and collapse during recent eruptions of Mount St. Helens, Washington (Vaughan et al., 2005; Schneider et al., 2008; Vallance et al., 2008), Augustine Volcano, Alaska (Wessels et al., 2010), and Redoubt Volcano, Alaska (Diefenbach et al., in press; Wessels et al., in press).

The various studies noted demonstrate that thermal imaging has become an important tool for monitoring spatial and temporal lava dome evolution as well as for understanding growth processes. However, previous thermal imaging studies of active lava domes have been conducted at andesitic or dacitic volcanoes. Here we present the first TIR imaging study of a rapidly-growing rhyolitic dome. The Chaitén lava dome complex exhibited dome growth rates in the early stages of the 2008-09 eruption that were two to three times greater than those typically seen at andesitic and dacitic lava domes (Pallister et al., 2013, this volume).

\section{Methods}

In this section we describe the operational setting, and the hardware and software used for acquiring and processing imagery and extracting temperatures. We also discuss the corrections applied to the raw images. Due to thermal camera availability, the three survey flights were conducted with three different cameras. The methodology is described in detail for only the 21 January 2009 observation flight. Similar techniques were utilized on the subsequent flights.

The observation flight of 21 January 2009 was conducted on a Fuerza Aérea de Chile (FACH) de Havilland Canada DHC-6 Twin Otter. The aft entry door was removed and the camera operator strapped to the floor of the aircraft. The survey was flown at an altitude of about 2,000 $\mathrm{m}$ and a slant range distance of approximately $1,500 \mathrm{~m}$ from the dome. We used a FLIR Systems ThermaCAM ${ }^{\mathrm{TM}}$ SC640 fitted with a standard $38 \mathrm{~mm}$ lens with a $24^{\circ}$ field of view. The instantaneous field of view per pixel is $0.66 \mathrm{mrad}$ giving a spatial resolution of $0.99 \mathrm{~m}$ at a distance of $1,500 \mathrm{~m}$. The instrument has a broadband detector covering the TIR portion of the spectrum from 7.5 to $13 \mu \mathrm{m}$. The detector is $16 \times 12 \mathrm{~mm}$ with $640 \times 480$ pixels ( 0.3 megapixels). The camera has three calibrated temperature ranges: $-40^{\circ}$ to $120^{\circ} \mathrm{C}$ (default setting), $0^{\circ}$ to $500^{\circ} \mathrm{C}$, and $300^{\circ}$ to $1,500^{\circ} \mathrm{C}$. On this flight we operated the camera in the $-40^{\circ}$ to $120^{\circ} \mathrm{C}$ range. According to the manufacturer the specified accuracy is $\pm 2^{\circ} \mathrm{C}$ or $2 \%$, whichever is greater.

Calibrated thermal video sequences were acquired and recorded directly to a laptop computer connected to the camera. Still images were extracted from the video sequences. These images were processed using FLIR Systems ThermaCAM Researcher ${ }^{\mathrm{TM}}$ version 2.3 software. Atmospheric corrections were made using the following parameters: thermal emissivity 0.95 , distance $1,500 \mathrm{~m}$, air temperature $18^{\circ} \mathrm{C}$, and relative humidity $80 \%$. Temperatures were not 
corrected for mixed pixels, surface orientation, daytime solar heating, or attenuation by volcanic ash or gases between the camera and the target (Ball and Pinkerton, 2006; Sawyer and Burton, 2006). We assumed that temperatures were homogeneous within each 1-m-resolution pixel size, that surface orientation was approximately perpendicular to the line of sight and that there were no attenuating gases or ash between the camera and the dome as flights were made in clear air. There are no nighttime thermal images of the dome from which to extract the daytime solar heating correction. Except for the daytime solar correction, which would reduce the apparent temperature, the other unapplied corrections would all increase the apparent temperature. Therefore, the temperatures obtained are probably minimum temperatures.

The second observation flight was conducted on 25 February 2009, about one week after a major dome collapse and generation of a pyroclastic density current (Major et al., 2013, this volume; Pallister et al., 2013, this volume). The thermal camera used on this flight was a FLIR Systems ThermaCAM ${ }^{\mathrm{TM}}$ P660 also with a $38 \mathrm{~mm}$ lens with a $24^{\circ}$ field of view. The specifications of the instrument are the same as for the SC640 described above. The calibrated temperature range was set to $0^{\circ}$ to $500^{\circ} \mathrm{C}$. Corrections were applied for distance, thermal emissivity, air temperature and relative humidity.

The observation flight on 24 January 2010 was conducted from a Bell 206 Long Ranger III helicopter at altitudes of 1,500 and 3,000 m. A Jenoptik (InfraTec) VarioCAM ${ }^{\circledR}$ thermal camera was used, operating within the wavelength range of 8 to $13 \mu \mathrm{m}$, with a resolution of 320x240 pixels and a field of view of $32^{\circ} \times 24^{\circ}$. The calibrated temperature range used was $0^{\circ}$ to $300^{\circ} \mathrm{C}$. Images were processed using InfraTec Irbis Plus 2.2 software. Similar correction values as used in the previous flights for thermal emissivity, air temperature and relative humidity were used in this flight. Details of the processing to produce temperature values are provided by Stevenson and Varley (2008).

Because our thermal images were obtained with three different cameras operating in different temperature calibration ranges, and because they were processed using two different software packages, the calibrated temperatures and temperature scales obtained from each survey may not be directly comparable. Furthermore, because the Chaitén lava dome complex is about $2 \times 3 \mathrm{~km}$ in size there are also important differences in distance and atmospheric attenuation between near and distant parts of the dome in a single image. We therefore, do not include temperature scales on the images. We present and interpret our results mostly qualitatively rather than quantitatively. We do, however, reference specific temperatures, rounded to the nearest $10^{\circ} \mathrm{C}$, where they are relevant to the discussion.

\section{Thermal imagery interpretation in the context of the eruption}

This section summarizes the evolution of the 20082009 Chaitén lava dome complex, describes its state on the dates of the three thermal imaging overflights, and notes changes between observation dates. The following descriptions of the evolution of the lava dome complex are based upon information provided in a series of 120 activity reports issued at regular and frequent intervals between 3 May 2008 and 15 June 2010 by the Observatorio Volcanológico de los Andes del Sur (OVDAS) operated by the Chilean Servicio Nacional de Geología y Minería (SERNAGEOMIN), and obtained from the SERNAGEOMIN website (www.sernageomin.cl). It should be noted that there were lengthy periods of time during which the growth of the dome and changes in its morphology, particularly the timing and initial appearance of new lobes, could not be monitored due to poor visibility, low clouds, or lack of observation flights. Descriptive terms for the dome complex (e.g., Dome 1, Dome 2, Dome 3) used in this paper follow the terminology used by OVDAS in their reports (Domo 1, Domo 2, Domo 3 and Pináculo). However, we replace pinnacle with spine, which is the commonly accepted nomenclature for this feature. Pallister et al. (2013, this volume) use a different terminology to describe the main features on the dome, labeling lobes by their date of extrusion. The OVDAS Domes 1, 2 and 3 respectively correspond to the May 2008, August and September 2008 and post-February 2009 lobes of Pallister et al. (2013, this volume) (Fig. 1, Table 1). Pallister et al. (2013, this volume) also provide a summary of the various phases of the eruption.

\subsection{Lava dome evolution from 1 May 2008 to 21 January 2009}

The initial explosive phase of the eruption (Phase 1 of Pallister et al., 2013, this volume) started late on 1 May 2008 (local time). On 3 May two vents 
(200 and $400 \mathrm{~m}$ in diameter) were seen on the north flank of the pre-existing lava dome. These vents were the source of the initial plinian eruptions. By 6 May they had merged into a single $800 \mathrm{~m}$ diameter crater that had grown to $1,000 \mathrm{~m}$ by 12 May. A new lava dome lobe occupying this crater was first observed on 21 May although seismicity indicates extrusion probably started on 12 May (Basualto et al., 2008). This lobe later came to be referred to as Dome 1 by OVDAS, and its appearance marks the start of the transitional explosive to exogenous phase of the eruption (Phase 2 of Pallister et al., 2013, this volume). By 25 May this new lobe extended above the old lava dome and a new 200-m-diameter crater had appeared south of the old lava dome summit. On 27 May two new craters were seen on the southern part of the old lava dome. 31 May is considered to be the end of the transitional phase and the beginning of the exogenous phase of the eruption (Phase 3 of Pallister et al., 2013, this volume). Northerly growth of the dome was noted on 4 June with additional southerly growth on 14 June. The upper surface of the old lava dome was mostly covered by 30 June. On 24 July a large depression, likely an explosion crater, was seen on the southern part of the lava dome complex. Sometime in the last week of July a partial lava dome collapse occurred on the eastern flank leaving a 500 -m-wide by 200 -m-high horseshoe shaped collapse scar. Assuming an angle of repose of $33^{\circ}$ for the slope of the talus abutting the lava dome within the crater moat, the volume of this partial lava dome collapse was probably on the order of $10 \times 10^{6} \mathrm{~m}^{3}$. Lower seismicity and ash column heights from early July to mid-September suggest a reduction in the extrusion rate. By 30 September the collapse scar had been enlarged by erosion, talus from lava dome growth toward the northeast had reached the caldera wall, the south sector depression appears to have filled in, and the maximum lava dome height exceeded the height of the caldera wall.

During an observation flight on 6 December 2008, OVDAS discovered that a second lava dome (called Dome 2) had extruded through and onto the northern part of Dome 1. Rockfall and block-andash flow activity was high on all flanks of Dome 2, including to the south onto the upper surface of Dome 1. Extrusion of Dome 2 could have started as early as late August 2008. The beginning of October 2008 corresponds to the start of a phase of spine extrusion and endogenous growth (Phase 4 of
Pallister et al., 2013, this volume). By 9 Jan 2009 talus from Domes 1 and 2 had reached the caldera walls on all sides, and a significant spine could be seen at the southeast edge of Dome 2 on the eastcentral side of the complex. Small failures from this spine generated numerous rockfalls, block-and-ash flows, and a small collapse to the east-southeast on 19 January 2009.

\subsection{The lava dome complex on 21 January 2009}

Several distinct components of the Chaitén lava dome complex are present in thermal images obtained during the 21 January 2009 overflight (Fig. 2). These include: 1. The pre-2008 lava dome, lying below Dome 1 talus on the north and south sides of the complex (cold); 2. Dome 1, mostly exposed in the southern half of the complex; 3. Dome 2, which is visible over the northern half of the complex flowing towards the north-northeast; 4. A large spine (pináculo in OVDAS reports) on the central-eastern part of the lava dome complex; 5. Talus deposits, both on top of Dome 1 and as an apron surrounding the lava dome complex; and 6. Extensive rockfall, block-and-ash flow, and collapse deposits in the moat between the lava dome complex and the caldera wall.

It is apparent from visible and thermal images that Domes 1 and 2 have quite different morphologies and surface textures (Figs. 2-4). Dome 1 has a massive aspect with an irregular coarse spiny surface texture, whereas Dome 2 has a smoother surface texture that exhibits fractures. The upper part of the Dome 2 lobe is mostly axisymmetric around its inferred vent (Fig. 3). The hemispherical shape of the upper part of Dome 2 suggests that it was extruded onto a relatively flat part of the pre-existing surface where it grew symmetrically around the vent until it impinged on the northern slope of the dome complex and developed into a large coulée (Fig. 3).

The Spine near the center of the lava dome complex was originally described in OVDAS reports as being part of Dome 2. It is not clear from these reports when the Spine started growing. Based on our interpretation of the thermal images from 21 January 2009, we consider Dome 2 and the Spine to be structurally independent. There appears to be a 'thermal divide' between Dome 2 and the Spine (Fig. 3b) suggesting that Dome 2 does not originate from the same location as the Spine. We also interpret the area of highest temperatures at the summit of 

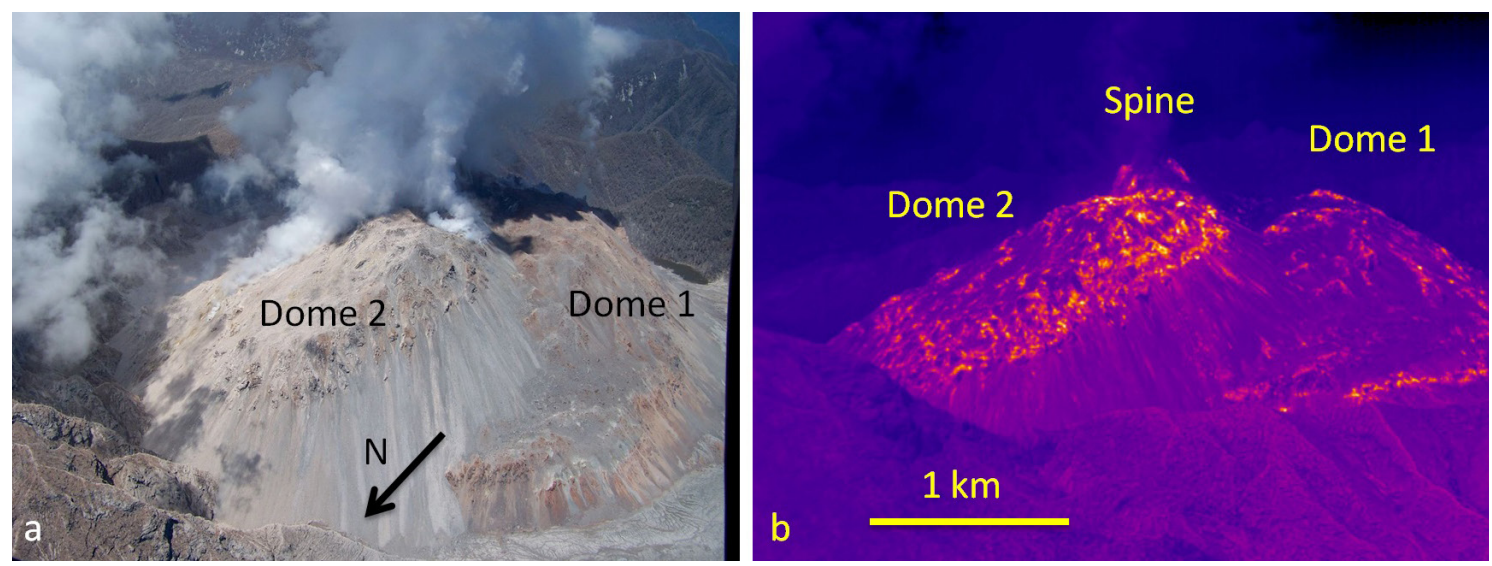

FIG. 2. a. View of the Chaitén lava dome complex looking southeast on 21 January 2009. b. Thermal image of Chaitén dome complex looking east on 21 January 2009 showing contrasting surface textures of Domes 1 and 2. Scale is approximate.

Dome 2 to be the likely location of its vent, more than $200 \mathrm{~m}$ away from the Spine (Figs. 3a and b).

A profile view of the southern part of Dome 1 looking west shows structures that can be interpreted as thrust faults or shear surfaces within the Dome 1 lobe (Fig. 3d). Alternatively, those structures may be contacts between sequentially stacked lobe units. The alternation of steeper and shallower slopes suggests lobe fronts and their associated talus deposits respectively. Shear-lobe-type extrusive structures are known from other lava domes. For example, at Soufrière Hills Volcano in Montserrat, such structures are typically the result of slow extrusion of relatively degassed magma detaching from the conduit wall (Watts et al., 2002). If the structures at Chaitén are thrust faults, they may have originated from displacements generated by the extrusion and growth of the large spine in the center of the lava dome complex.

Notably colder areas are visible on the lava dome complex in the thermal images (Figs. 2 and 3). Some of these cold areas are parts of the pre-2008 lava dome beneath Domes 1 and 2; others are recent talus deposits. Some of these colder areas may be isolated remnants of pre-2008 lava dome that were uplifted by endogenous growth of Dome 1, or early carapace of new lava that had already thickened and cooled to near ambient temperature. Because these cold areas are visible in several images taken from different orientations they are unlikely to be the result of attenuation by gas or ash between the camera and the dome.

\subsection{Lava dome evolution between 21 January 2009 and 25 February 2009}

Between the January and February 2009 overflights, OVDAS reports indicate that all three components of the lava dome (Domes 1, 2, and the Spine) continued to grow. This implies that there was simultaneous growth of Domes 1 and 2 and the Spine from distinct vents. On 19 February, a large partial dome collapse occurred marking the beginning of the final endogenous phase of the eruption (Phase 5 of Pallister et al., 2013, this volume). The collapse scar was oriented southwest from the Spine and was about $500 \mathrm{~m}$ long, $300 \mathrm{~m}$ wide and had walls up to $200 \mathrm{~m}$ high. Collapse volume is estimated around $20 \times 10^{6} \mathrm{~m}^{3}$. Even though the upper part of the collapse scar surrounds the Spine from SE to NW the Spine itself appears not to have been significantly involved in the collapse (Fig. $3 \mathrm{~b}$ of Pallister et al., 2013, this volume). Collapse deposits fill the moat between the lava dome complex and the caldera wall from the south through the west (Fig.1). Seismicity indicates the partial dome collapse and related phenomena lasted 3 hours and 18 minutes (OVDAS reports from 19 and 20 February 2009). One possible trigger for the partial dome collapse is disruption and structural destabilization of Dome 1 resulting from penetration of the Spine immediately adjacent to the region involved in the collapse. Another possible trigger is the loading of the upper part of Dome 1 adjacent to the Spine by material shed from the Spine. Hydrothermal alteration of the underlying pre-2008 lava dome may also have played a role. 

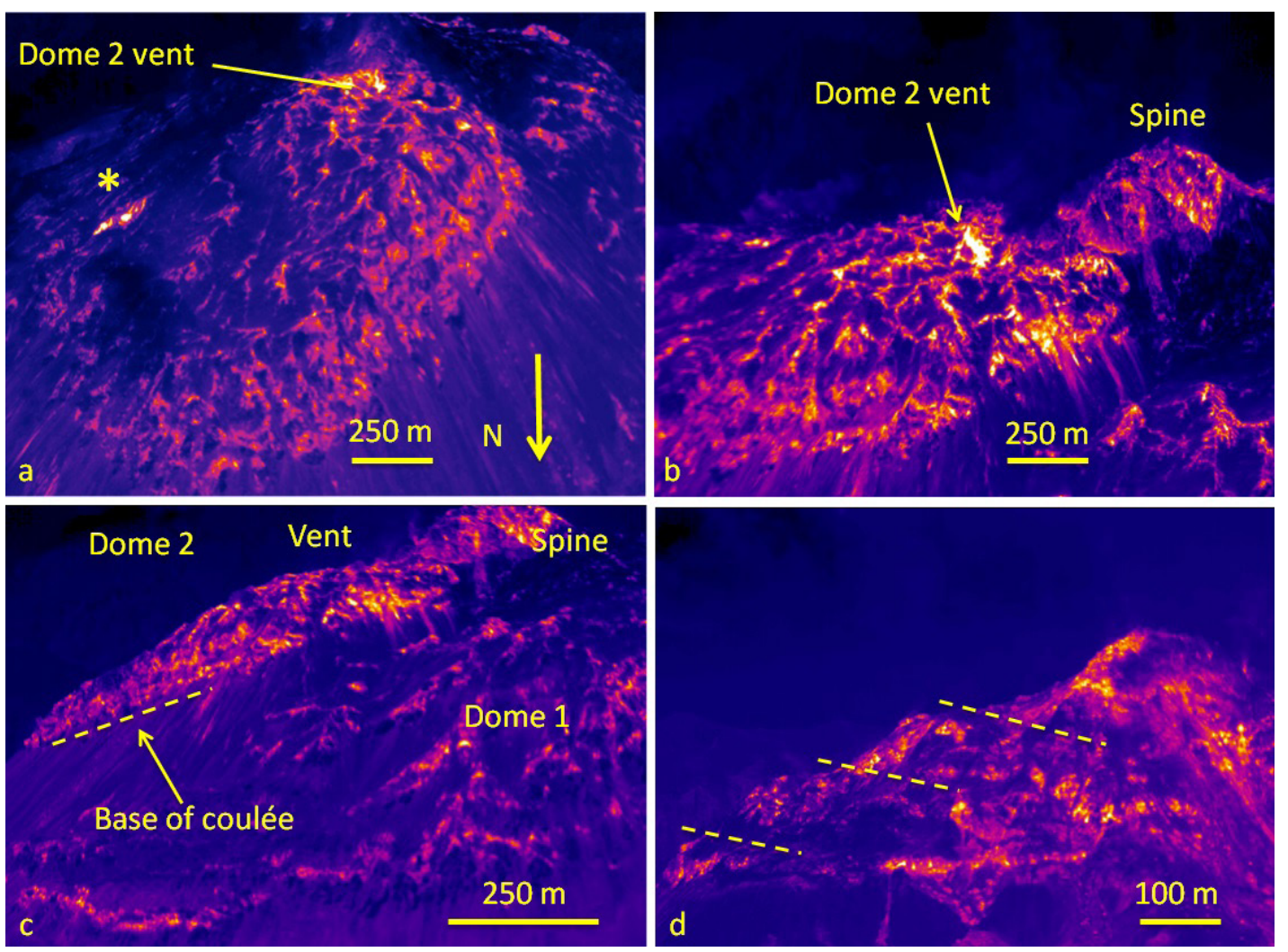

FIG. 3. Thermal images of the Chaitén lava dome complex on 21 January 2009. Scales are approximate. a. Oblique view from the north of the northern part of the Chaitén dome complex on 21 January 2009. The asterisk indicates the location of the thermal feature on the lower eastern side of Dome 2 discussed in the text. b. Same location as Fig. 3 A looking southeast. The brightest area in both images indicates the hottest temperatures associated with the likely location of the Dome 2 vent. Note that the Spine is thermally and structurally distinct from Dome 2. c. Oblique view looking east of the northern part of the dome complex. Dome 2 is flowing north-northeast over the top of the northern portion of Dome 1. The base of the coulée is indicated by a dashed line at the top of the talus slope. Contrast the spiny texture of Dome 1 in the foreground with the smoother axisymmetric profile of the summit portion of Dome 2 on the horizon. d. Profile view of the southern part of Dome 1 looking west. The dashed lines indicate the locations of possible shear planes between stacked extrusive shear lobes. Note the alternation of steeper and shallower slopes corresponding to the active flow faces (lobe fronts) and adjacent talus respectively. Alternatively, these planes could be thrust faults caused by deformation due to invasive growth of the Spine to the north.

\subsection{Lava dome complex on 25 February 2009}

Thermal images acquired on 25 February (Figs. 4a though d) are consistent with the reported continued growth of both Dome 1 and the Spine. The Spine had temperatures near $400^{\circ} \mathrm{C}$ around the western side of its base, indicating that it was recently emplaced. Some of the hot areas on the Spine may also have been areas where carapace had been removed by recent rockfalls exposing hotter interior. The extensive thermal features on the west side of the Spine might be a result of destabilization of this side of the Spine as the result of the partial dome collapse of 19 February 2009. Dome 2 appeared to have changed little between the sets of thermal images acquired on 21 January and 25 February. It displayed fewer areas of enhanced temperature in February than it did in January. The lack of physical change and apparently diminished temperature indicate that the rate of growth of this part of the lava dome complex had decreased and may have stagnated. On 25 February, there was a hot spot on the lower eastern flank of Dome 2 with temperatures near $300^{\circ} \mathrm{C}$ (Figs. $4 \mathrm{~b}$ and c). This area also existed on 21 January 2009 (Fig. 3a). This hot spot likely is a persistent fumarole, although no condensation 

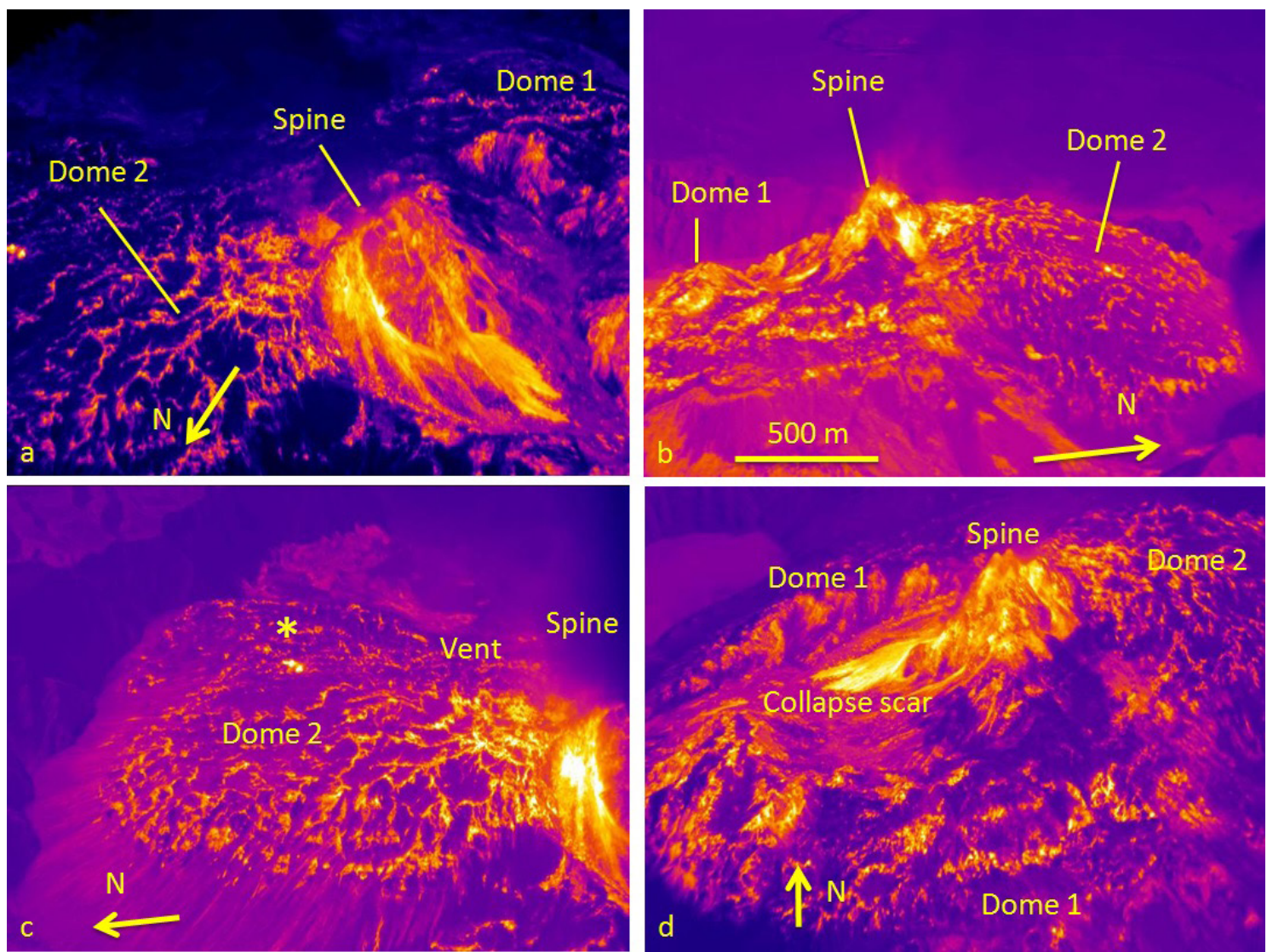

FIG. 4. High-angle oblique thermal images of the Chaitén lava dome complex on 25 February 2009. Scale is approximate and applies to all images. a. West side of the Spine with active mass wasting into the adjacent 19 February 2009 collapse scar in the foreground. Maximum temperatures are near $400^{\circ} \mathrm{C}$, indicating the Spine is either still extruding, or that the hot interior of the Spine core has been exposed by mass wasting. b. Image of the eastern side of the dome complex. c. View of Dome 2 looking east. The asterisk indicates the location of the hot spot with temperature near $300^{\circ} \mathrm{C}$ discussed in the text. Spine is on right side of image shedding hot rockfalls. d. View looking north with Spine perched above a crescent-shaped collapse scar that has been excavated into Dome 1 .

plume is visible on any of the images. It also may be a local collapse feature or fracture in the lobe carapace exposing the hotter interior. Another possibility is that it is a diapir of hotter and less dense material that has risen through the denser and cooler outer part of the flow lobe, similar to features described in rhyolite flows at Little Glass Mountain, California (USA) (Fink, 1983; Fink and Manley, 1987).

The location of the Dome 2 vent is not as clear in the 25 February images as it was in the 21 January 2009 images. Several factors may account for this: 1. The vent of Dome 2 may have migrated southward toward the Spine; 2 . The upper part of Dome 2 may have sagged into the topographic saddle between Dome 2 and the Spine; 3. The vent for Dome 2 may have been incorrectly inferred in the earlier images; or 4. The vent was no longer active. Some temperatures exceeding $200^{\circ} \mathrm{C}$ on Dome 1 adjacent to the collapse scar may be the result of removal of colder carapace during the 19 February 2009 partial dome collapse.

\subsection{Lava dome evolution between 25 February 2009 and 24 January 2010}

According to OVDAS weekly reports, overall lava dome growth continued throughout the remainder of 2009 and possibly into January 2010, albeit at a very slow rate. Between February 2009 and January 2010, dome growth appeared to be concentrated in the 
central and southwestern parts of the lava dome complex. This concentrated growth generated numerous rockfalls, small collapses of the dome, and small block-and-ash flows that were trapped mainly within the southwest part of the caldera. The most noteworthy event during this period was the appearance of Dome 3 (OVDAS Domo 3) within the 19 February 2009 collapse scar, first observed during a flight on 29 September 2009.

Due to poor weather conditions and limited observations, the growth history of Dome 3 is poorly constrained. It could have started growing in the collapse scar as early as February 2009 , shortly after the 19 February dome collapse, although it is not visible in the 25 February 2009 images (Fig. 4d). At the Soufrière Hills Volcano in Montserrat, new dome growth within a collapse scar immediately following a dome collapse was relatively common e.g., on 20 May 2006 (Loughlin et al., 2010).

Other major changes in the overall morphology of the Chaitén dome complex on 29 September 2009 include the inferred collapse of the Spine and the appearance of an elongated depression extending eastward from Dome 3. The origin of this depression is speculative; it could be structural such as a cleft between two lobes extruding in different directions, or it could be an explosion crater, though no large explosions were reported during this phase of eruption. It could also be the result of a westward expansion of the scar from the partial dome collapse on the east side of the lava dome complex in July 2008 , or perhaps an undocumented collapse event sometime in late 2009.

\subsection{Lava dome on 24 January 2010}

By 24 January 2010 the number, size and temperatures of hot areas on the lava dome complex had decreased significantly (Figs. 5c and d). Zones with elevated temperatures were found close to the rim around the scar left by the 19 February 2009 collapse from the southwest sector of the dome complex. A small lobe had temperatures near $200^{\circ} \mathrm{C}$, and another area on the dome had maximum pixel temperatures near $270^{\circ} \mathrm{C}$. These hotspots could be isolated areas of residual dome growth or possibly hot rock surrounding active fumaroles, though there is no obvious correlation between the hot areas and active fumarole condensation plumes (Fig. 5d). Dome 3 cannot be seen in the January 2010 images due to an extensive fumarolic and degassing plume from the central part of the complex.

\section{Discussion}

Between January 2009 and January 2010, three sets of thermal images of the Chaitén lava dome complex indicated a general decrease in extrusive activity. That decrease in activity is apparent in decreased surface temperatures and the gradual disappearance of thermal features. The initially extruded lava, Dome 1, is active throughout the period of observation, but its extrusion rate decreased significantly. By January 2010, only one possible area of growth on Dome 1 remained visible. A second area of extrusion on the dome complex, Dome 2, appears to have stopped growing in early 2009, because no new thermal features were visible on it in images acquired in February 2009. A prominent spine visible in the January 2009 images is less prominent in the February 2009 images. Its decreased prominence might be the result of mass wasting of its western side into a collapse scar that formed on 19 February 2009. A third extrusion of lava, which formed Dome 3, was not directly observed during our thermal imaging flights.

One of the more interesting aspects of the Chaitén lava dome complex is the variety of simultaneous lava-dome-growth behavior exhibited. It appears that in January 2009, Dome 1 was growing both endogenously (spiny carapace texture) and exogenously (shear lobes), Dome 2 was flowing northward, and a degassed spine was being extruded. There were also multiple explosion craters and simultaneous explosive and extrusive activity in May 2008 (Pallister et al., 2013, this volume). Although some lava domes, such as the Brujo dome at Santiaguito, Guatemala, may exhibit all of these growth styles at some point in their development, it is less common to see them occurring simultaneously in a single lava dome. Simultaneously active features on the Chaitén lava-dome complex suggest that lava extruded from multiple flow paths from the underlying conduit to the surface of the lava dome. Separate vents for Dome 2, Dome 3 and the Spine are further evidence for this. Multiple flow paths have been shown to form in analog models of lava flows, and they most likely exist in lava domes (Anderson et al., 2005). An example is the Soufrière Hills Volcano in Montserrat. At various times between 2008 and 

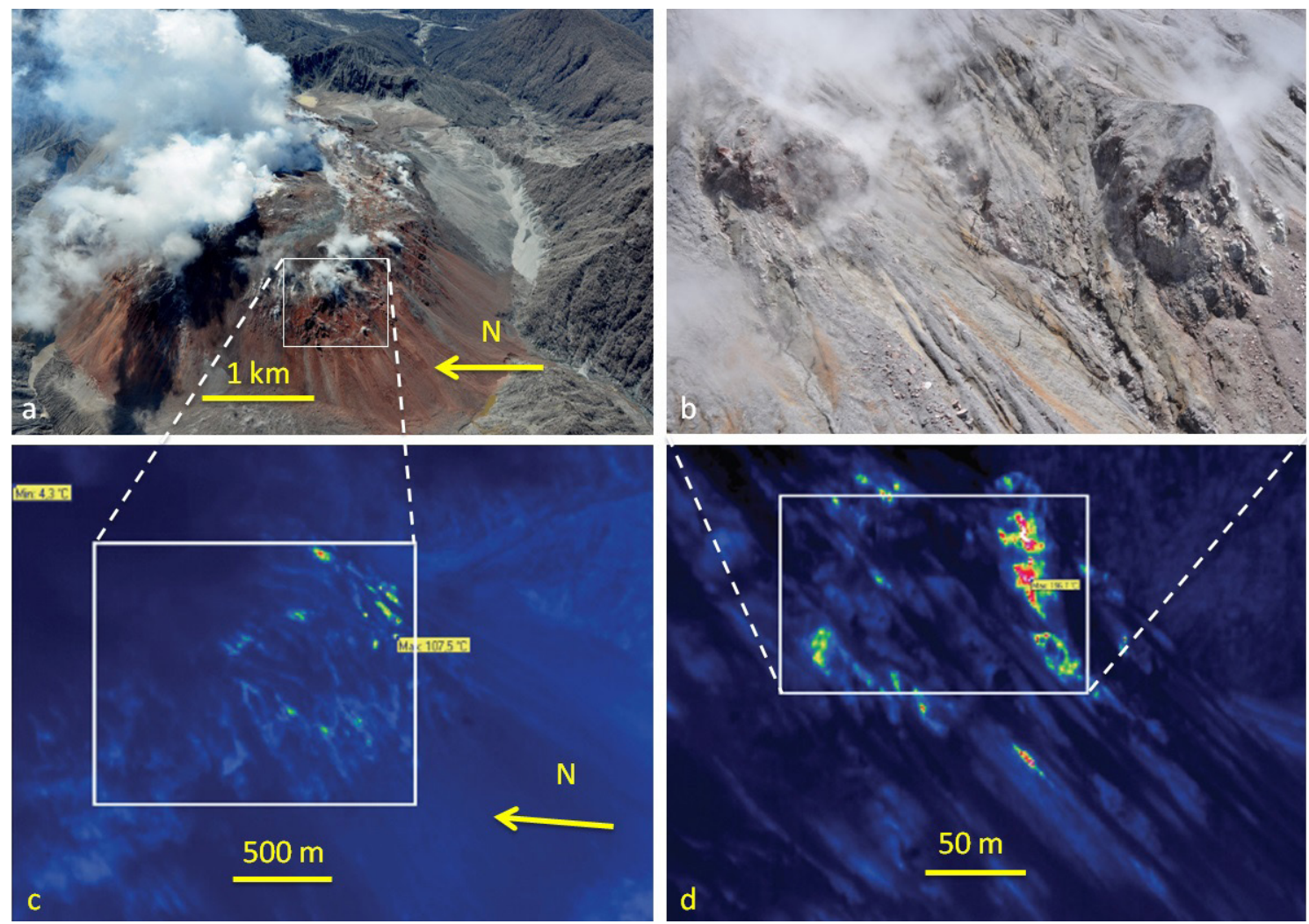

FIG. 5. Visible and thermal images of the Chaitén lava dome complex on 24 January 2010. Scales are approximate. a and c. Highangle oblique visible and thermal views of the southwestern part of the Chaitén lava dome complex looking east. The boxes in $5 \mathrm{a}$ and $5 \mathrm{c}$ indicate the approximate corresponding locations. Maximum temperature is about $110^{\circ} \mathrm{C}$. b and $\mathbf{d}$. Close-up visible and thermal views of an area on the southwestern flank. The hot area (maximum temperature near $200^{\circ} \mathrm{C}$ ) may be the result of minor residual lava extrusion or of recent rockfalls that have exposed the hotter interior beneath the carapace. This may also be fumarole-heated rock, although no condensation plume appears to be associated with the hottest areas.

2012, the dome complex at SHV has vented tephra from its summit crater, from the base of a collapse scar on its north flank, and from the Gages vent on its west side (Cole et al., 2010).

At Chaitén Volcano, the depth of the conduit from which multiple flow paths diverge is not known. That conduit could be located at the base of the pre-2008 dome or deeper. The original depth of the pre-historic caldera is unknown. Alternatively, divergence to multiple flow paths could occur within the pre-2008 dome complex. The concept of multiple pathways is probably untenable if the divergence originated at the altitude of the caldera moat when the eruption began in May 2008. Divergence at that altitude would require unrealistic changes in flow direction within the dome complex. If the point of divergence is deeper, it could be at an altitude corresponding to the base of the caldera floor beneath the base of the old lava dome, which could be several hundred meters below the level of the moat. In order to generate multiple flow paths, rising magma must work its way through and diverge within the brecciated caldera fill, or there could be several feeder dikes underlying the old lava dome. In either of those scenarios, there could be more than one path of least resistance between the top of the conduit and the surface (Fig. 6).

Contrasts in growth styles between Dome 1, Dome 2 and the Spine reflect the rheology of the lava. In the classification of Fink and Griffiths (1998), derived from analog experiments, Dome 1 is a spiny textured lava dome, and Dome 2 (the lower part of which is morphologically a coulée) is an axisymmetric textured lava dome that has been elongated by gravity along slope. These surface textures are indicative of 
slow growing/fast cooling, and fast growing/slow cooling lava lobes, respectively. The apparent contrast in surface textures also could be due to differences in temperature, $\mathrm{SiO}_{2}$ content, water content, and crystal and vesicle content, as well as to extrusion rate. Petrological data, however, indicate that there is little or no compositional difference between the different lobes (Pallister et al., 2013, this volume). Therefore, the simplest explanation for the difference in morphology and surface textures between Domes 1 and 2 is that Dome 2 had a higher extrusion rate.

Although the overall rates of dome growth obtained from volume differences by Pallister et al. (2013, this volume) decreased from the time Dome1 was extruded to the time Dome 2 was extruded (May through September 2008), the overall trend of decreasing growth rate does not distinguish between the relative growth rates of individual lobes, or between endogenous and exogenous growth. The diminishing rate of dome growth therefore does not contradict Dome 2 having a higher extrusion rate than Dome 1 during August and September 2008. Faster extrusion of Dome 2 could have compensated slower extrusion of Dome 1 and the Spine, and/or a reduced endogenous growth rate. Pallister et al. (2013, this volume) also report that the obsidian in Dome 2 tends to be more devitrified than the obsidian of Dome 1, and it has a higher microlite content. This is consistent with Dome 2 having a greater ratio of advection rate to cooling rate than does Dome 1 , as indicated by its axisymmetric morphology around its vent. Pallister et al. (2013, this volume) show that the newly effused lava and the pre-2008 rocks are compositionally indistinguishable. Since all the lobes are compositionally similar and separate batches of magma supplied the 2008-2009 lavas and the pre2008 lavas, it is conceivable that separate batches of magma fed Domes 1 and 2 at different rates. The Spine evidently had greater yield strength and viscosity than Domes 1 and 2, as it extruded as an essentially solid body. It may have been more extensively degassed, had a lower extrusion temperature, or perhaps a

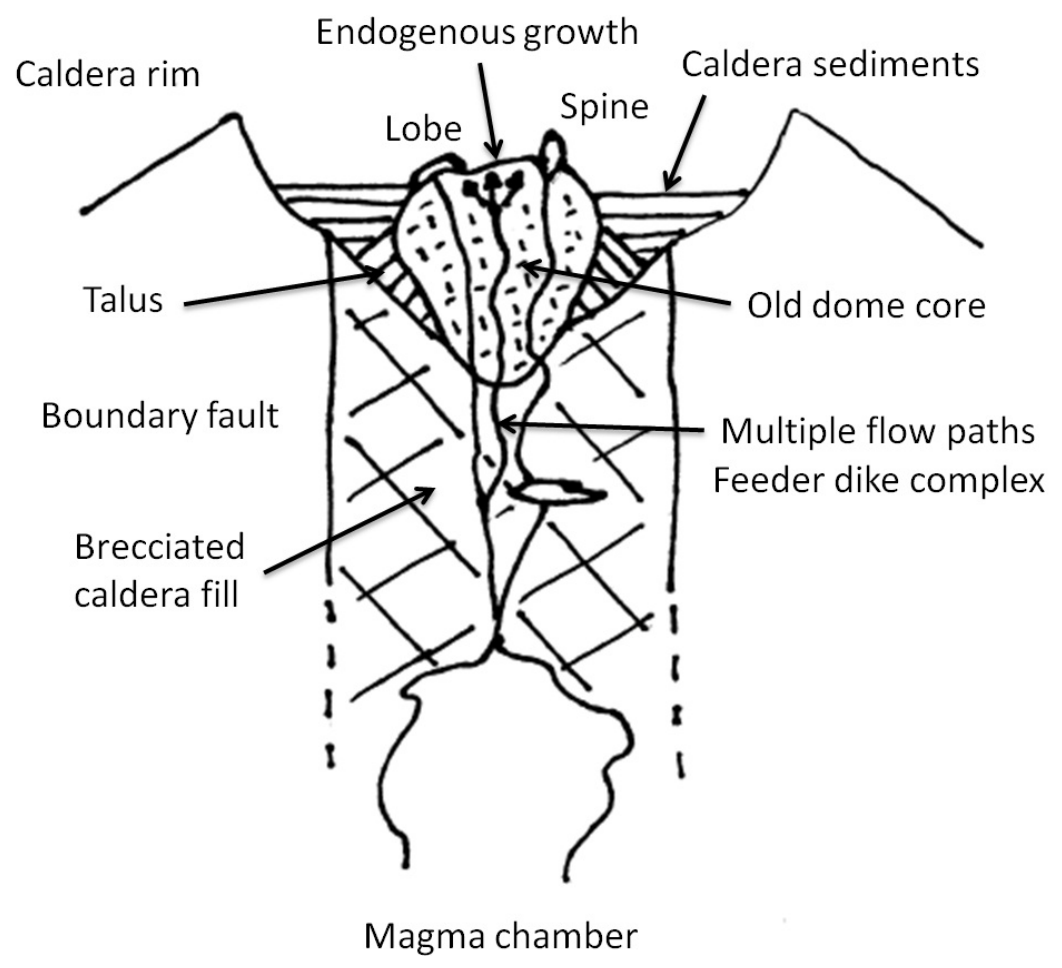

FIG. 6. Conceptual cross-section of the Chaiten lava dome complex illustrating possible multiple flow paths between the top of the magma chamber and the upper part of the dome complex. Variations in flow path lengths within the lava dome and corresponding differences in transit times may have an effect on the properties of individual lobes. Most of the dome core probably predates the 2008-2010 activity. Figure is not to scale. 
higher crystal content. There are no compositional or petrographic data available for the Spine.

Another variable that could affect the morphology of Dome 2 is the slope of the underlying surface. Studies at Mount St. Helens have shown that the angle of the underlying slope onto which lava extrudes can be an important factor in controlling lobe texture (Anderson and Fink, 1990). However, at Chaitén the upper part of Dome 2 can be seen to have an axisymmetric geometry about the presumed location of the vent (Fig. 3). This geometry implies that the underlying surface beneath the upper part of Dome 2 is relatively flat. So even though the lower part of the coulée clearly exists because of the slope, this does not explain the axisymmetric texture and shape of the upper part of Dome 2, which most likely resulted owing to its high extrusion rate (Fink and Griffiths, 1998).

Differences in extrusion rate and rheology could also be related to different transit times caused by dome pathway effects (Fig. 6). Lava domes are heterogeneous constructs made up of multiple domains with varying rheological, mechanical and structural properties. Magma rising through more resistant portions of the heterogeneous dome would progress more slowly towards the surface and therefore have more time for degassing, crystal growth and cooling to occur. Upon reaching the surface of the dome, a more degassed, crystal-rich lava would likely extrude relatively slowly. Generally, magma rising through the dome will follow the path of least resistance to the surface. Therefore, parts of the dome complex that are hotter, less viscous, more fractured, and have a thinner more easily penetrated carapace are the most likely pathways through which magma will rise. Conversely magma intruding into the dome complex through a less preferential pathway (colder, more viscous, or less fractured part of the dome) would take longer and be subjected to time-dependent rheological changes that could impact its extrusive growth style. Unfavorable pathways may also cause intruding magma to pond and stagnate within the dome resulting in endogenous growth.

\section{Summary}

Airborne thermal images of the Chaitén rhyolite lava dome were obtained on three occasions between January 2009 and January 2010. These were useful for understanding the nature and pace of growth of the newly extruded lava. They also revealed contrasting growth styles affecting different parts of the lava dome. Observed synchronous endogenous and exogenous growth habits were likely the result of multiple flow paths within the lava dome. We suggest that contrasts in morphology and surface texture between Domes 1 and 2 are the result of Dome 2 being extruded rapidly relative to Dome 1.

\section{Acknowledgments}

This manuscript was considerably improved thanks to reviews by J. Major, J. Pallister and M. Ramsey. We would also like to thank Oficina Nacional de Emergencia (ONEMI), Servicio Nacional de Geología y Minería (SERNAGEOMIN) and the Observatorio Volcanológico de los Andes del Sur (OVDAS), Fuerza Aérea de Chile (FACH) and the United States Geological Survey (USGS) for facilitating the survey flights. Bernstein and Calder acknowledge support from the University at Buffalo, the Geological Society of America (GSA), and National Science Foundation grant EAR-0809543, Pavez from Santander Fellowship, Varley from the Universidad de Colima for travel support, and Whelley from GSA and the National Aeronautics and Space Administration (NASA).

\section{References}

Alfano, F.; Bonadonna, C.; Gurioli, L. 2012. Insights into eruption dynamics from textural analysis: the case of the May, 2008, Chaitén eruption. Bulletin of Volcanology 74 (9): 2095-2108.

Alfano, F.; Bonadonna, C.; Volentik, A.C.M.; Connor, C.B.; Watt, S.F.L.; Pyle, D.M.; Connor, L.J. 2011. Tephra stratigraphy and eruptive volume of the May, 2008, Chaitén eruption, Chile. Bulletin of Volcanology 73 (5): 613-630.

Anderson, S.W.; Fink, J.H. 1990. The Development and Distribution of Surface Textures at the Mount St. Helens Dome. In Lava Flows and Domes (Fink, J.H.; editor). Springer-Verlag 2: 25-46. Berlin.

Anderson, S.W.; McColley, S.M.; Fink, J.H.; Hudson, R.K. 2005. The development of fluid instabilities and preferred pathways in lava flow interiors: Insights from analog experiments and fractal analysis. In Kinematics and Dynamics of Lava Flows (Manga, M.; Ventura, G.; editors). Geological Society of America, Special Paper 396: 147-161. Boulder.

Ball, M.; Pinkerton, H. 2006. Factors affecting the accuracy of thermal imaging cameras in volcanology. Journal of Geophysical Research 111 (B11203). doi: 10.1029/2005JB003829. 
Basualto, D.; Pena, P.; Delgado, C.; Moreno, H.; Muñoz, J.O. 2008. Seismic activity related to the evolution of the explosive eruption of Chaitén Volcano in the Southern Andes Volcanic Zone. In Eos, Transactions of the American Geophysical Union 89 (53), Fall Meeting Supplement, Abstract V43D-2178, San Francisco.

Carn, S.; Pallister, J.S.; Lara, L.; Ewert, J.W.; Watt, S.; Prata, A.J.; Thomas, R.J.; Villarosa, G. 2009. The unexpected awakening of Chaitén Volcano, Chile. In Eos, Transactions of the American Geophysical Union 90 (24): 205-206.

Carter, A.J.; Girina, O.; Ramsey, M.S.; Demyanchuk, Y.V. 2008. ASTER and field observations of the 24 December 2006 eruption of Bezymianny Volcano, Russia. Remote Sensing of Environment 112 (5): 2569-2577.

Carter, A.J.; Ramsey, M.S. 2009. ASTER- and field-based observations at Bezymianny Volcano: Focus on the 11 May 2007 pyroclastic flow deposit. Remote Sensing of Environment 113 (10): 2142-2151.

Carter, A.J.; Ramsey, M.S.; Belousov, A.B. 2007. Detection of a new summit crater on Bezymianny Volcano lava dome: satellite and field-based thermal data. Bulletin of Volcanology 69 (7): 811-815.

Castro, J.M.; Cordonnier, B.; Tuffen, H.; Tobin, M.J.; Puskar, L.; Martin, M.C.; Bechtel, H.A. 2012. The role of melt-fracture degassing in defusing explosive rhyolite eruptions at volcan Chaitén. Earth and Planetary Science Letters 333-334: 63-69.

Castro, J.M.; Dingwell, D.B. 2009. Rapid ascent of rhyolitic magma at Chaitén Volcano, Chile. Nature 461 (7265): 780-783.

Cole, P.; Bass, V.; Christopher, T.; Eligon, C.; Fergus,M.; Gunn, L.; Odbert, H.; Simpson, R.; Stewart, R.; Stinton, A.; Stone, J.; Syers, R.; Robertson, R.; Bernstein, M.; Watts, R.; Williams, P. 2010. Report on Activity between 15 August 2009 and 28 February 2010, Part 1, Montserrat Volcano Observatory, Open File Report OFR 10-01a: 57 p.

Diefenbach, A.K.; Bull, K.F.; Wessels, R.L.; McGimsey, R.G. In press. Photogrammetric monitoring of lava dome growth during the 2009 eruption of Redoubt Volcano. Journal of Volcanology and Geothermal Research.

Durant, A.J.; Villarosa, G.; Rose, W.I.; Delmelle, P.; Prata, A.J.; Viramonte, J.G. 2012. Long-range volcanic ash transport and fallout during the 2008 eruption of Chaitén Volcano, Chile. Physics and Chemistry of the Earth 45-46: 50-64.
Fink, J.H. 1983. Structure and emplacement of a rhyolite obsidian flow: Little Glass Mountain, Medicine Lake Highland, northern California. Geological Society of America Bulletin 94: 362-380.

Fink, J.H.; Griffiths, R.W. 1998. Morphology, eruption rates, and rheology of lava domes: Insights from laboratory models. Journal of Geophysical Research 103 (B1): 527-545.

Fink, J.H.; Manley, C.R. 1987. Origin of pumiceous and glassy textures in rhyolitic flows and domes. In The Emplacement of Silicic Domes and Lava Flows (Fink, J.H.; editor). Geological Society of America, Special Paper 212: 77-88. Boulder.

Friedman, J.D.; Frank, D.; Kieffer, H.H.; Sawatzky, D.L. 1981. Thermal infrared surveys of the May 18 crater, subsequent lava domes, and associated volcanic deposits. In The 1980 Eruptions of Mount St. Helens (Lipman, P.W.; Mullineaux, D.R.; editors). United States Geological Survey, Professional Paper 1250: 279-293. Washington, D.C.

Griggs, R.F., 1922. The Valley of Ten Thousand Smokes. National Geographic Society: 341 p. Washington, D.C.

Hildreth, W.; Fierstein, J. 2012. The Novarupta-Katmai Eruption of 1912 - Largest Eruption of the Twentieth Century: Centennial Perspectives. United States Geological Survey, Professional Paper 1791: 260 p. Reston.

Kieffer, H.H.; Frank, D.; Friedman, J.D. 1981. Thermal infrared surveys at Mount St. Helens-Observations prior to the eruption of May 18. In The 1980 Eruptions of Mount St. Helens (Lipman, P.W.; Mullineaux, D.R.; editors). United States Geological Survey, Professional Paper 1250: 257-277. Washington, D.C.

Lara, L.E. 2009. The 2008 eruption of the Chaitén Volcano, Chile: a preliminary report. Andean Geology 36 (1): 125-129.

Lara, L.E.; Moreno, H.; Amigo, A.; Hoblitt, R.P.; Pierson, T.C. 2013. Late Holocene history of Chaitén Volcano: New evidence for a $17^{\text {th }}$ century eruption. Andean Geology 40 (2): 249-261.

Loughlin, S.C.; Luckett, R.; Ryan, G.; Christopher, T.; Hards, V.; De Angelis, S.; Jones, L.; Strutt, M. 2010. An overview of lava dome evolution, dome collapse and cyclicity at Soufrière Hills Volcano, Montserrat, 2005-2007. Geophysical Research Letters 37 (L00E16). doi: 10.1029/2010GL042547.

Lowenstern, J.B.; Bleick, H.; Vazquez, J.A.; Castro, J.M.; Larson, P.B. 2012. Degassing of Cl, F, Li, and Be during extrusion and crystallization of the rhyolite dome at Volcán Chaitén, Chile during 2008 and 2009. Bulletin of Volcanology 74 (10): 2303-2319. 
Major, J.J.; Lara, L.E. 2013. Overview of Chaitén Volcano, Chile, and its 2008-2009 eruption. Andean Geology 40 (2): 196-215.

Major, J.J.; Pierson, T.C.; Hoblitt, R.P.; Moreno, H. 2013. Pyroclastic density currents associated with the 2008-2009 eruption of Chaitén Volcano (Chile): Forest disturbances, deposits and dynamics. Andean Geology 40 (2): 324-358.

Naranjo, J.A.; Stern, C.R. 2004. Tefrocronología holocena de la parte más austral $\left(42^{\circ} 30^{\prime}-45^{\circ} \mathrm{S}\right)$ de la Zona Volcánica Andina del Sur. Revista Geológica de Chile 31 (2): 225-240.

Pallister, J.S.; Diefenbach, A.; Burton, W.; Muñoz, J.; Griswold, J.; Lara, L.; Lowenstern, J. 2013. The Chaitén rhyolite lava dome: Eruption sequence, lava dome volumes, rapid effusion rates and source of the rhyolite magma. Andean Geology 40 (2): 277-294.

Ramsey, M.S.; Harris, A.J.L. 2013. Volcanology 2020: How will thermal remote sensing of volcanic surface activity evolve over the next decade? Journal of Volcanology and Geothermal Research 249: 217-233.

Ramsey, M.S.; Wessels, R.L.; Anderson, S.W. 2012. Surface textures and dynamics of the 2005 lava dome at Shiveluch Volcano, Kamchatka. Geological Society of America Bulletin 124 (5-6): 678-689.

Sahetapy-Engel, S.T.; Harris, A.J.L. 2009. Thermal structure and heat loss at the summit crater of an active lava dome. Bulletin of Volcanology 71 (1): 15-28.

Sawyer, G.; Burton, M. 2006. Effects of a volcanic plume on thermal imaging data. Geophysical Research Letters 33 (L14311). doi: 10.1029/2005GL025320.

Schneider, D.J.; Vallance, J.W.; Wessels, R.L.; Logan, M.; Ramsey, M.S. 2008. Use of Thermal Infrared Imaging for Monitoring Renewed Dome Growth at Mount St. Helens, 2004. In A Volcano Rekindled: The Renewed Eruption of Mount St. Helens, 2004-2006 (Sherrod, D.R.; Scott, W.E.; Stauffer, P.H.; editors). United States Geological Survey, Professional Paper 1750: 347-359. Reston.

Spampinato, L.; Calvari, S.; Oppenheimer, C.; Boschi, E. 2011. Volcano surveillance using infrared cameras. Earth-Science Reviews 106 (1-2): 63-91.

Stevenson, J.; Varley, N. 2008. Fumarole monitoring with a handheld infrared camera: Volcán de Colima, México, 2006-2007. Journal of Volcanology and Geothermal Research 177 (4): 911-924.

Umakoshi, K.; Shimizu, H.; Matsuwo, N.; Ohta, K. 1992. Surface temperature measurements of lava domes and pyroclastic flows by infrared thermal video system. In
Unzen Volcano the 1990-1992 Eruption (Yanagi,T.; Okada, H.; Ohta, K.; editors). Nishinippon and Kyushu University Press: 44-48. Fukuoka.

Vallance, J.; Schneider, D.; Schilling, S. 2008. Growth of the 2004-2006 lava-dome complex at Mount St. Helens. In A Volcano Rekindled: The Renewed Eruption of Mount St. Helens, 2004-2006 (Sherrod, D.R.; Scott, W.E.; Stauffer, P.H.; editors). United States Geological Survey, Professional Paper 1750: 169-208. Reston.

Vaughan, R.G.; Hook, S.J.; Ramsey, M.S.; Realmuto, V.J.; Schneider, D.J. 2005. Monitoring eruptive activity at Mount St. Helens with TIR image data. Geophysical Research Letters 32 (L19305). doi: 10.1029/2005GL024112.

Watt, S.F.L.; Pyle, D.M.; Mather, T.A. 2013. Evidence of mid- to late-Holocene explosive rhyolitic eruptions from Chaitén Volcano, Chile. Andean Geology 40 (2): 216-226.

Watt, S.F.L.; Pyle, D.M.; Mather, T.A.; Martin, R.S.; Matthews, N.E. 2009. Fallout and distribution of volcanic ash over Argentina following the May 2008 explosive eruption of Chaitén, Chile. Journal of Geophysical Research 114 (B04207). doi: 10.1029/2008JB006219.

Watts, R.B.; Herd, R.A.; Sparks, R.S.J.; Young, S.R. 2002. Growth patterns and emplacement of the andesitic lava dome at Soufrière Hills Volcano, Montserrat. In The Eruption of Soufrière Hills Volcano, Montserrat, from 1995 to 1999 (Druitt, T.H.; Kokelaar, B.P.; editors). The Geological Society, Memoir 21: 115152. London.

Wessels, R.; Coombs, M.; Schneider, D.; Dehn, J.; Ramsey, M. 2010. High-resolution satellite and airborne thermal infrared imaging of the 2006 eruption of Augustine Volcano, Alaska. In The 2006 Eruptions of Augustine Volcano, Alaska (Power, J.A.; Coombs, M.L.; Freymueller, J.T.; editors). United States Geological Survey, Professional Paper 1769: 527-552. Reston.

Wessels, R.L.; Vaughan, R.G.; Patrick, M.R.; Coombs, M.L. In press. High-resolution satellite and airborne thermal infrared imaging of precursory unrest and 2009 eruption at Redoubt Volcano, Alaska. Journal of Volcanology and Geothermal Research.

Wicks, C.; De la Llera, J.C.; Lara, L.E.; Lowenstern,J. 2011. The role of dyking and fault control in the rapid onset of eruption at Chaitén Volcano, Chile. Nature 478 (7369): 374-377. 